\begin{tabular}{|c|c|}
\hline & $\begin{array}{l}\text { International Journal of Health Sciences } \\
\text { Available online at wwww.sciencescholar.us } \\
\text { Vol. } 4 \text { No. 3, December 2020, pages: } 69-74 \\
\text { e-ISS: 250-696X, p-ISSN: } 2550-6978 \\
\text { https://doio.org/10.29332/jhhs.v4n3.464 }\end{array}$ \\
\hline
\end{tabular}

\title{
The Relationship On Health Education Against Anxiety Concerning COVID-19 Transmission
}

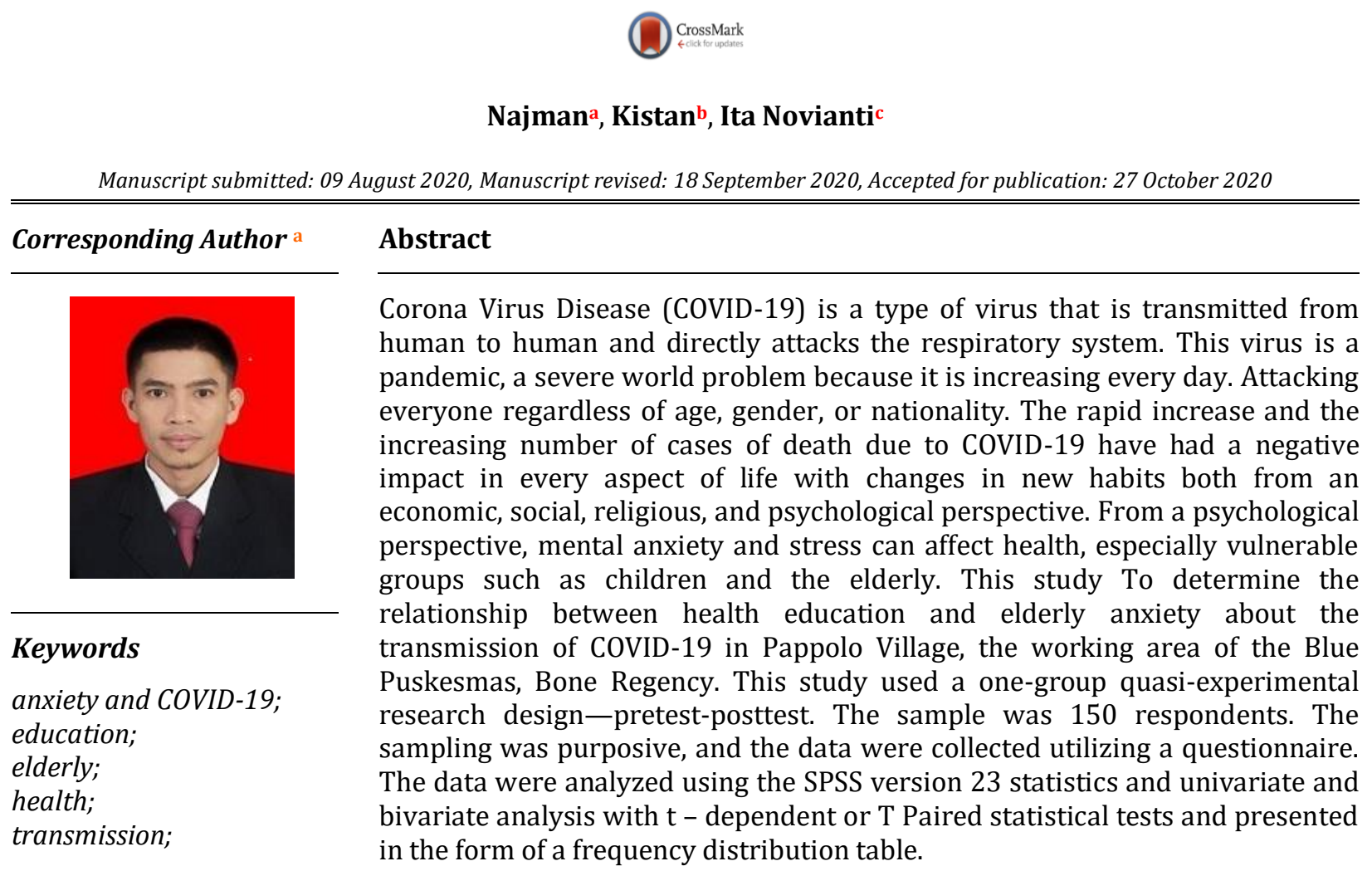

International Journal of Health Sciences (C) 2020.

This is an open access article under the CC BY-NC-ND license (https://creativecommons.org/licenses/by-nc-nd/4.0/).

\section{Contents}

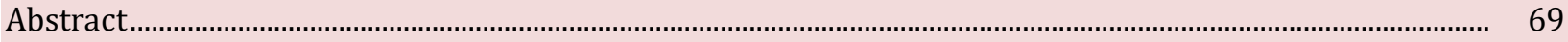

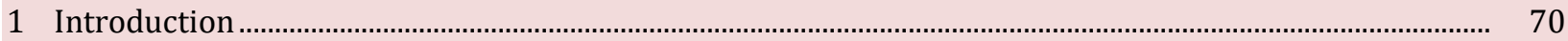

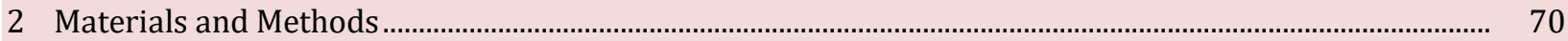

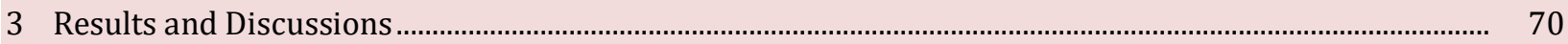

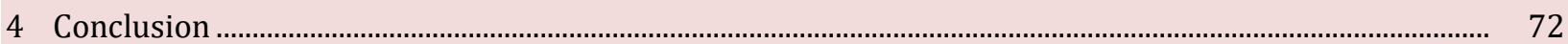

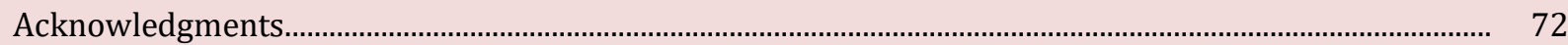

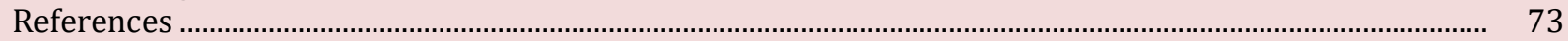

a Batari Toja Nursing Academy, Indonesia

b Batari Toja Nursing Academy, Indonesia

${ }^{\mathrm{c}}$ Batari Toja Watampone Midwifery Academy, Indonesia 


\section{Introduction}

COVID-19 is a type of virus that is transmitted from human to human and directly attacks the respiratory system. This virus is a pandemic, a severe world problem because it is increasing every day. Attacking everyone regardless of age, gender, or nationality (Jaji, 2020). According to Kistan \& Musni (2020), since the government implemented the new ordinary policy, there is undoubtedly a risk of increasing COVID-19 cases in Indonesia. Data from WHO (2020), on September 21, 30,949,804 were confirmed positive, 959,115 died, and about there were 272,585 new cases found around the world. Meanwhile, at the same time, the distribution data in Indonesia recorded 248,852 patients, 180,797 were declared cured, and 9,677 die. It explains that the increase in Corona cases around the world continues to increase, including Indonesia (Ministry of Health, 2020). The rapid growth and the increasing number of cases of death due to COVID-19 have had a negative impact in every aspect of life with changes in new habits both from an economic, social, religious, and psychological perspective.

From a psychological standpoint, it is mental anxiety, and stress can affect health, especially for vulnerable groups such as children and the elderly (Ilpaj \& Nurwati, 2020). The age factor and lack of knowledge can be the reasons for anxiety and worry, excessive fear that disturbs and reduces the immunity of the human body so that it is very vulnerable to being exposed or affected by COVID-19. In general, the exemption is the body's response to defend the body against foreign bodies, both molecular and cellular (Gumantan et al., 2020). Besides, not a few older adults have chronic diseases, such as heart disease, diabetes, asthma, or cancer. It has made it even more at risk with an increasing number of older adults who are exposed to Covid-19 every day (Fullana et al., 2020; Asmundson et al., 2020). The phenomenon found the field, and from the observations of many researchers found that people of all ages seem uneasy and feel excessive fear. It will lower the body's immune system so that it will be more susceptible to the Corona Virus (Huang \& Zhao, 2020; Mazza et al., 2020; Mann et al., 2020). To make people calmer and stay alert, they must have good knowledge of mental health education to increase public knowledge and insight. Based on this background, researchers are interested in knowing the relationship of health education to elderly anxiety about the transmission of Corona Virus Disease (COVID 19) in Pappolo Village, the working area of Puskesmas Biru, Bone Regency.

\section{Materials and Methods}

This research method used a quasi-experimental research design with a one group pretest-postest approach. The goal of this study was to determine the effect of health education on elderly anxiety about the transmission of Corona Virus Disease (COVID-19). Determination of the sample using a non-random sampling technique with a purposive sampling type so that the sample is the elderly who are assisted by Puskesmas Biru Kab. Bone number of 150 respondents who met the inclusion criteria. The instrument used to measure anxiety is a questionnaire that was previously tested for validation and reliability-anxiety measured before being given health education and one week after being given health education. Data were analyzed using a statistical test-dependent t-test with a significant level of $\alpha=0.05$.

\section{Results and Discussions}

Table 1

Gender distribution of respondents

\begin{tabular}{lll}
\hline Gender & Frequencies (n) & Percentage (\%) \\
\hline Male & 74 & 49.3 \\
Female & 76 & 50.7 \\
Total & 150 & 100,0 \\
\hline
\end{tabular}

Source: Primary data, 2020 
Table 1 found that the majority of respondents were female is 76 (49.3\%) of respondents, and the male gender is $74(50.7 \%)$ of respondents.

Table 2

Distribution of the elderly by age

\begin{tabular}{lll}
\hline Age & Frequencies (n) & Percentage (\%) \\
\hline $55-60$ ys & 70 & 46,7 \\
$61-70$ ys & 59 & 39,3 \\
$<71$ ys & 21 & 14 \\
Total & 150 & $100 \%$ \\
\hline
\end{tabular}

Source: Primary data, 2020

The table 2 shows that the majority of respondents are around 55 - 60 years old is 70 (46.7\%) respondents, around 55 - 60 years as many as $59(39.3 \%)$ respondents, and around < 71 years $21(14 \%)$ respondents.

Table 3

Distribution of respondents by anxiety transmission COVID-19 before and after the intervention is to the elderly in urban village Puskesmas Pappolo Blue

\begin{tabular}{llll}
\hline Covid-19 Transmission Anxiety & Mean & SD & N \\
\hline Pre Education Intervention & 16.45 & 4,619 & 150 \\
Post Education Intervention & 16,09 & 3,744 & 150 \\
\hline
\end{tabular}

Source: Primary data, 2020

Table 3 shows that as many as 150 samples, on average, anxiety about COVID-19 transmission before educational interventions was 16.45 with a standard deviation of 4.619. Meanwhile, the moderate anxiety about Covid-19 transmission after the educational intervention was 16.09, with a standard deviation of 3.744.

Table 4

The $\mathrm{t}$ - a dependent test of the relationship between health education and anxiety in the elderly in Pappolo Village, the Blue Health Center work area

\begin{tabular}{llll}
\hline Covid-19 Transmission Anxiety & Mean & SD & P-Value \\
\hline Before Educational Intervention & 16.45 & 4,619 & 0,018 \\
& 16,09 & 3,744 & \\
\hline
\end{tabular}

Source: Primary data, 2020

The statistical test results obtained that the p-value is $0.000<0.05$, it can be said that there is a significant difference between anxiety before being given and after being given health education about the transmission of COVID-19 in the elderly who are assisted by the Blue District Health Center Bone.

\section{Respondent characteristics}

The results of statistical tests showed that the female gender faced more anxiety and those aged 54-60 years experienced more stress. Balkhi et al. (2020), found that men tend to wash their hands more often than women. However, in general, the ratio between the sexes was not significantly different with only slight changes such as men being more likely to be afraid to leave the house after the pandemic, pretending to be sick to avoid coming to work or college, and considering quitting or taking time off. Meanwhile, women are more likely to buy more food to stock for fear of running out. The study found that over 35 years of age felt

Najman, N., Kistan, K., \& Novianti, I. (2020). The relationship on health education against anxiety concerning COVID-19 transmission. International Journal of Health Sciences, 4(3), 69-74. https://doi.org/10.29332/ijhs.v4n3.464 
more anxious compared to the 35-year-old group because those under 35 felt anxious due to watching or reading and listening to news about COVID-19.

Research results George, et al. in John W, Santrock, older adults have a higher likelihood of experiencing anxiety disorders than depression. This statement was supported by Tamber \& Noorkasiani in Suryani \& Rosyid (2016). They revealed that the psychological problems that mostly occur in the elderly include anxiety, loneliness, and feelings of sadness (Annisa \& Ifdil, 2016) research conducted by Bergman et al. (2020), corroborates this statement, Cohen-Fridel et al. (2020), which explains that elderly anxiety is a concern about physical health during the COVID-19 disease pandemic. The study found that health concern in the elderly is associated with anxiety and seen among older people with high levels of anxiety.

The Relationship of Health Education to Elderly Anxiety about Covid-19 Transmission The results of statistical tests using the Paired T-test, before and after being given education, obtained a significant value of $0.018<0.05$, so it concluded that there was a significant difference between anxiety about COVID-19 transmission before and after being given an education. This study is in line with Anjarini (2018), with a sample size of 31 families aged 40-65 years using the Non-Equavalent Control Group design, the Wilcoxon test results found that there were differences in the two groups, where the experimental group obtained a p-value of 0.000 which means there is an influence health education on family anxiety.

As a new disease, there is little known about the COVID-19 pandemic. Moreover, humans tend to be afraid of something they do not know yet, which causes symptoms such as prejudice against other people, not wanting to socialize with other people, and tends not to do activities just staying at home (Dai, 2020; Datta \& Tiwari, 2016). One of the symptoms of anxiety is feeling worried that bad things will happen, excessive worry, irritability, and difficulty relaxing. COVID-19 is a new source of stress and anxiety (Thakur \& Jain, 2020) behavior. Educational activities are carried out by disseminating information and messages and instilling confidence so that people are not only aware, know, and understand but also willing and able to accept and implement recommendations.

They have to do with health (Anjarini, 2018) The expected result of health education is a change in the mindset and attitude of individuals, families, and communities to be able to instill a healthy mindset and principles in daily life to achieve optimal health degree. According to the assumption, the researchers explained that education about the transmission of COVID-19 is a collective obligation, education in the form of correct and unambiguous information can only obtaining from competent health workers. The elderly need special attention from health workers because they are a vulnerable group affected by the transmission of COVID-19. This trend is in line with research by Li et al. (2020), found that accurate health information about COVID-19 is needed to increase public awareness of health.

\section{Conclusion}

The results of research on the relationship of health education to elderly anxiety about the transmission of Corona Virus Disease (COVID - 19) in Pappolo Village, the working area of Puskesmas Biru, Bone Regency, it concluded that there is a significant difference in the frequency of anxiety about COVID-19 before the intervention and after the intervention. Health Education.

\section{Acknowledgments}

The completion of this research cannot be separated from the support of various parties. Researchers specifically express their deepest gratitude to the Director of the Batari Toja Watampone Nursing Academy, Puskesmas Biru, district. Bone, All Respondents, and the people of Pappolo Village, Tanete Riattang Subdistrict, Bone Regency, and all those who have helped, provide suggestions and input as well as an encouragement both moral and material. 


\section{References}

Anjarini, A. D. (2018). The Effect of Health Education on Family Anxiety. Stikes Bakti Husada Mulia Madiun. Annisa, D. F., \& Ifdil, I. (2016). Konsep kecemasan (anxiety) pada lanjut usia (lansia). Konselor, 5(2), 93-99.

Asmundson, G. J., Paluszek, M. M., Landry, C. A., Rachor, G. S., McKay, D., \& Taylor, S. (2020). Do pre-existing anxiety-related and mood disorders differentially impact COVID-19 stress responses and coping?. Journal of anxiety disorders, 74, 102271. https://doi.org/10.1016/j.janxdis.2020.102271

Balkhi, F., Nasir, A., Zehra, A., \& Riaz, R. (2020). Psychological and Behavioral Response to the Coronavirus (COVID-19) Pandemic. Cureus, 12(5).

Bergman, Y. S., Cohen-Fridel, S., Shrira, A., Bodner, E., \& Palgi, Y. (2020). COVID-19 health worries and anxiety symptoms among older adults: the moderating role of ageism. International psychogeriatrics, 1-5.

Dai, N.F. (2020). Community Stigma against the Covid-19 Pandemic. National Proceedings of Covid-19, 66-73.

Datta, C., \& Tiwari, P. (2016). Impact of environmental degradation on human health. International research journal of management, IT and social sciences, 3(1), 1-6.

Fullana, M. A., Hidalgo-Mazzei, D., Vieta, E., \& Radua, J. (2020). Coping behaviors associated with decreased anxiety and depressive symptoms during the COVID-19 pandemic and lockdown. Journal of Affective Disorders, 275, 80-81. https://doi.org/10.1016/j.jad.2020.06.027

Gumantan, A., Mahfud, I., \& Yuliandra, R. (2020). A person's level of anxiety about the implementation of the new normal and knowledge of body immunity. Sport science and education journal, 1(2).

Huang, Y., \& Zhao, N. (2020). Generalized anxiety disorder, depressive symptoms and sleep quality during COVID-19 outbreak in China: a web-based cross-sectional survey. Psychiatry research, 112954. https://doi.org/10.1016/j.psychres.2020.112954

Ilpaj, S. M., \& Nurwati, N. (2020). Analysis of the Effect of Death Rates Due to Covid-19 on Mental Health in Indonesia. Focus: Journal of Social Work, 3(1), 16-28.

Jaji, J. (2020). The Effect of Health Education with Leafletter Media on Citizen Knowledge in Preventing Covid Transmission 19. Paper presented at the Proceeding of the National Nursing Seminar.

Kistan, K., \& Musni, M. (2020). The relationship between knowledge, attitude, and readiness of the academic community in Covid-19 spread prevention: Batari Toja Nursing Academy, Watampone. International journal of health \& medical sciences, 3(1), 72-78.

Li, W., Liao, J., Li, Q., Baskota, M., Wang, X., Tang, Y., ... \& Fukuoka, T. (2020). Public health education for parents during the outbreak of COVID-19: a rapid review. Annals of translational medicine, $8(10)$.

Mann, F. D., Krueger, R. F., \& Vohs, K. D. (2020). Personal economic anxiety in response to COVID19. Personality and Individual Differences, 167, 110233. https://doi.org/10.1016/j.paid.2020.110233

Mazza, M. G., De Lorenzo, R., Conte, C., Poletti, S., Vai, B., Bollettini, I., ... \& Benedetti, F. (2020). Anxiety and depression in COVID-19 survivors: Role of inflammatory and clinical predictors. Brain, behavior, and immunity, 89, 594-600. https://doi.org/10.1016/j.bbi.2020.07.037

Ministry of Health. (2020). Corona Disease Virus Update.

Suryani, A., \& Rosyid, F. N. (2016). The Relationship Between Anxiety Level and Quality of Life of the Elderly at the Wredha Bhakti Bhakti Pajang Surakarta (Doctoral dissertation, Muhammadiyah University of Surakarta).

Thakur, V., \& Jain, A. (2020). COVID 2019-suicides: A global psychological pandemic. Brain, behavior, and immunity.

WHO. (2020).Corona Virus Disease Update.

Najman, N., Kistan, K., \& Novianti, I. (2020). The relationship on health education against anxiety concerning COVID-19 transmission. International Journal of Health Sciences, 4(3), 69-74. https://doi.org/10.29332/ijhs.v4n3.464 


\section{Biography of Authors}

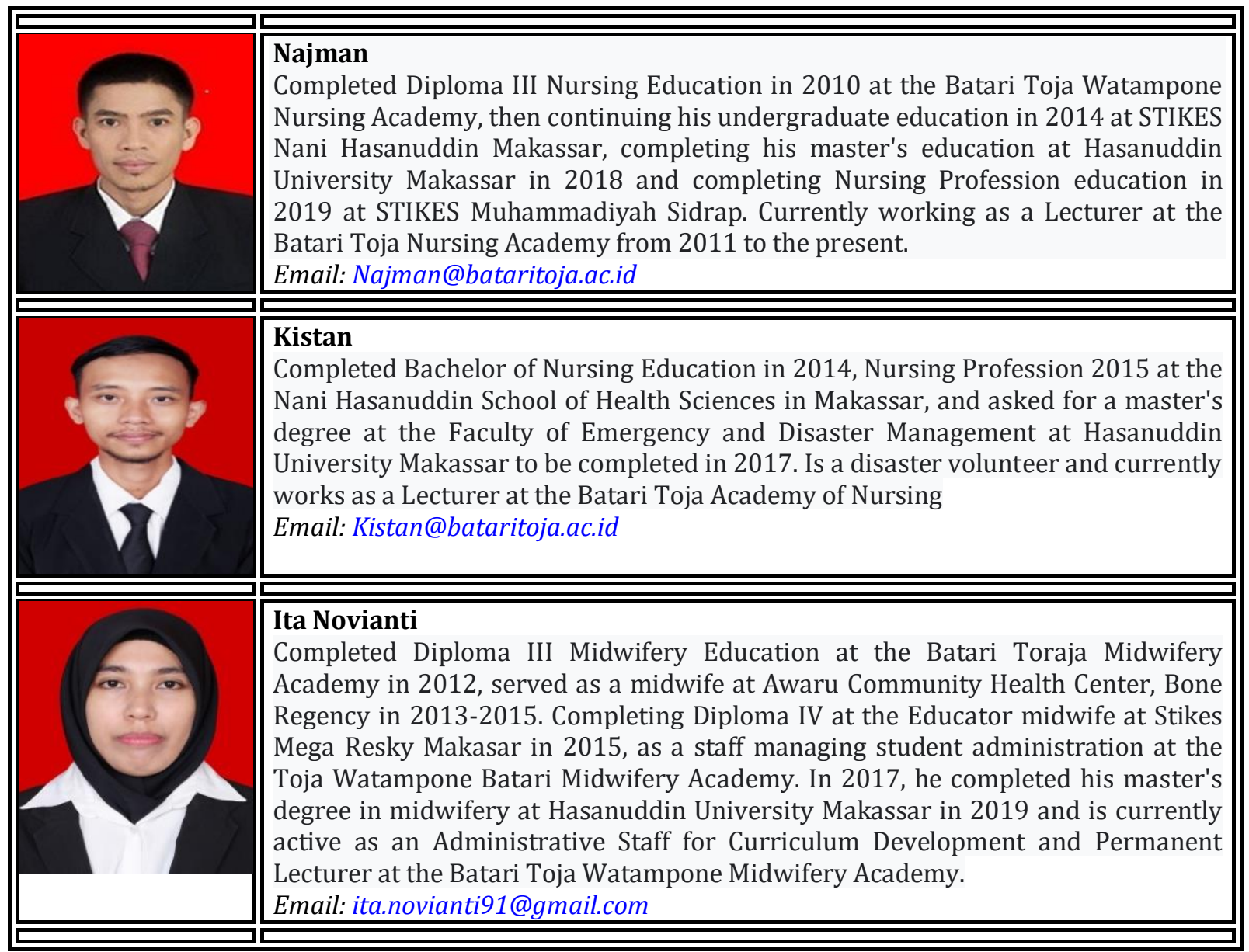

